\title{
Regional Agriculture, Food Supply Systems and Competitiveness of Agriculture Prodiction Industries in Stavropol Territory
}

\author{
Elena Nikolaevna Lapina ${ }^{1}$, Natalia Vladimirovna Sobchenko ${ }^{1}$, Larisa Vladimirovna Kuleshova ${ }^{1} \&$ Svetlana \\ Yurievna Shamrina ${ }^{1}$ \\ ${ }^{1}$ Stavropol State Agrarian University, Stavropol, Russian Federation \\ Correspondence: Elena Nikolaevna Lapina, Stavropol State Agrarian University, Zootechnicheskiy Ln, 12, \\ Stavropol, 355017, Russian Federation. E-mail: viklapin2013@yandex.ru
}

$\begin{array}{lc}\text { Received: November 14, } 2014 & \text { Accepted: November 24, } 2014 \quad \text { Online Published: February 25, } 2015 \\ \text { doi:10.5539/ass.v11n6p92 } & \text { URL: http://dx.doi.org/10.5539/ass.v11n6p92 }\end{array}$

\begin{abstract}
The article is devoted to the issue of ensuring the competitiveness of the agriculture and food system currently present in Stavropol Territory. Provision of the local population with locally manufactured food products in sufficient quantities and of the appropriate quality is one of the main challenges for the regional authorities. Assesment for the most advantageous trends for developing agriculture sector in Stavropol Krai considering its supply security, production costs and market demands for the manufactured products is quite essential. Results of the assesment ensured preparation of the market maps for Stavropol Territory with reference to the main product groups, that allowed to rank them in accordance with the identified indicators. To assess efficiency of the industries, the analysis of the investment strategic positions within the main agriculture product groups was prepared and involved imlementation of adjusted BCG matrix. Based on the obtained data the following was prepared: ranking for agricultural industries considering their socio-economic importance for the Stavropol Territory, and recommendations on the feasible trends for particular industries.
\end{abstract}

Keywords: food security, agricultural market, food market, product group, matrix BCG

\section{Introduction}

Among the major strategic objectives in Russian food doctrine it is necessary to highlight formation of the efficient national market for agricultural products which is influenced by the particular features of the regional markets and global trends (Veeman \& Veeman, 2004; Urban, 2010).

The main economic factors affecting formation and development of the market for agricultural products are offer and demand, which should be studied in close connection (Tomilina, Glotova, \& Kuzmenko, 2013; Garmann, 2014). Nevertheless, in accordance with the market rule of law, it is the demand in particular that determines the offer. Market assesment to identify the demand is necessary to determine the total volume of sales of certain goods for a certain period of time.

The particular markets were suggested as the subject for the assesment and they were identified within the certain main groups of agricultural products as follows: grain; meat and meat products; milk and dairy products; potatoes; vegetables and table melons; fruits and berries; eggs and egg products; fish and fish products (Sklyarov \& Sklyarova, 2013; Trukhachev, 2013).

Comparative gradual record of self-sufficiency of the Stavropol Territory, the North Caucasus Region and the Russian Federation showed that the Stavropol Territory is self-sufficient in grain, meat and milk, while the North Caucasus Region is self-sufficient in grain and vegetables, and Russia is self-sufficient in grain.

Deficiency in the locally manufactured products is balanced by the import from other regions and abroad. Comparison of import and export of products helps to determine the trends in the trade. For example, production of fruits and berries is a sector that shows heavy importing. At the same time, Territorial and Regional markets show higher degree of market openness for grain, meat, milk, eggs and fish, whereas the National one is open for grains, milk, eggs. Therefore the level of market concentration is reduced and it entails increased competition preasure from the foreign suppliers (Food security and agrarian problems of the Russian economy, 2011; Jones \& Davidson, 2014).

However, undertaken inventory dynamics analysis indicates sufficient food security in all product groups and 
types of markets.

\section{Method}

Food security has been a subject for devoted works with many foreign and domestic scholars such as F. Quesnay, Adam Smith, T. Maltus, D. Rikkardo, K. Marx, N. Kondratiev, A. Chayanov, N. Bukharin, S. Afanasyev, V. Balabanov, N. Radugin, Y.Sklyarova, N. Kharitonov, G. Anania, R. Nisticò, F. G. Baquedano, W. M. Liefert, M. Veeman, T. Veeman, etc. Despite the fact that food security is given a lot of attention in economics science, we must admit that many aspects of this problem are currently not sufficiently advanced. All this requires the study on viability of development for certain product groups (Rudoi, 2011; Evdokimova, 2009).

The works devoted to the prioritizing some food groups over the others and their ranking so far have not been systemized and were implemented as parts of other researches. In this context, the aim of this work is to justify the selection of investment-attractive sectors of agriculture, and seek to improve the food production efficiency. In accordance with the purpose the following main objectives were defined: identify and quantify the indicators characterizing the sufficiency of domestic food products in the local market; examine the level of sufficiency in meeting the population needs in food produce; analyze strategic investment positions for agricultural commodity groups.

Fulfillment of the goals and objectives of this work was supported by the following research methods: analytical, monographic, abstract logics, constructive calculations, economic and mathematical modeling.

\section{Results}

Generalized data for resource balances and resourse utilization in the context of product groups allowed us to calculate the numbers for the following indicators:

- The level of self-suficiency with the main types of agricultural products-represented as a ratio of production in the territory to its domestic consumption. Domestic consumption includes industrial consumption, private consumption (consumption fund), loss of production, and non-food purpose processing;

- Import dependancy of the basic goods in the food groups-represented as a ratio of all goods imported to the territiry (including import from abroad) to the total volume of resources;

- Import consumption of the basic goods in the food groups-represented as a ratio of all goods imported to the territiry (including import from abroad) to domestic consumption;

- Trade balance of essential commodities in the food groups-represented as the difference between the export of goods, including export abroad, to import of goods (including import from abroad);

- The level of exports for basic comodities within the food groups-represented as the ratio of export of goods (including export abroad) to production;

- Volume of trade for basic comodities within the food groups-represented as the sum of imports to the territory (including imports from abroad) and exports (including exports from abroad);

- Coefficiency for the agricultural market avalability-represented as the ratio of foreign trade turnover of the main comodities in the food groups to their production:

$$
K_{o}=\left(Q_{i}+Q_{e}\right) / T V A P,
$$

where Ko-is the coefficient of availability,

Qi-quota for imports of agricultural products,

Qe-quota for exports of agricultural products,

TVAP-total volume of agricultural production .

If $\mathrm{Ko}=(\mathrm{Q} \mathrm{i}+\mathrm{Qe}) / \mathrm{TVAP}>1$-then it is the importing industry;

If $\mathrm{Ko}=(\mathrm{Qi}+\mathrm{Qe}) / \mathrm{TVAP}<1$-then it is the exporting industry.

When the degree of market availability is increased the level of market concentration is reduced, and that to a certain extend leads to the increased competition preasure from the external suppliers (Syomin \& Kibirov, 2013; Baquedano \& Liefert, 2014). It can be estimated by means of charging the share of imported goods (including imports from abroad) in the total saleslevel at the particular comodity market. This indicator also draws the red line where addressing the issues related to preventive measures to protect domestic producers become necessary. 


\subsection{Statistics and Data Analysis}

Comparative gradual record of self-sufficiency of the Stavropol Territory, the North Caucasus Region and the Russian Federation showed that the Stavropol Territory is self-sufficient in grain, meat and milk, while the North Caucasus Region is self-sufficient in grain and vegetables, and Russia is self-sufficient in grain.

Lack of local produce resources is balanced by import from other regions and abroad. Local territorial market is most import depended on fruit (share of imports ranges from $44.7 \%$ to $46.9 \%$ ) and in fish by more than $65 \%$. Also in the Stavropol Territory there has been evident declining of import dependency in potatoes and vegetables (almost by 2), and significant increase of imports in meat (almost by 2), milk-by $35.5 \%$, eggs by 1.8 times.

Regional market is most import depended in fruit, the share of imports may come up to $52 \%$. In the North Caucasus region there has been evidence of declining imports in potatoes by $10 \%$ and vegetables by $3 \%$, a significant increase of imports in meat and milk-by $30 \%$, eggs-by $44 \%$.

The national market shows high import dependancy in fruits-to $60 \%$, and meat-more than $20 \%$. Import dependancy is decreasing in potatoes by $17 \%$, vegetables by $3 \%$, and meat-265, whereas increase of import dependence is in both milk and wheat by $14 \%$, and eggs-by $50 \%$.

During the assessed period the level of import consumption in Stavropol Territory increased in the meat by 2.5 times, in milk-by 1.4 times, in fruit and eggs-by $5.1 \%$; decrease of import consumption was shown in grains by $60 \%$, potatoes-by $45 \%$, vegetables- $47 \%$. The level of import consumption in the Region increased in the meat by 1.5 times, in milk-by 1.4 times, in eggs-by 1.4 times, in potatos-by $1 \%$, in vegetables-by $4 \%$. The level of import consumption in Russia increassed by $7 \%$ grain, milk-14\%, eggs-by 1.5 times, the meat fell by $26 \%$, potatoes-by $17 \%$, vegetables- $3 \%$.

With the shown trends in import dependancy and import consumption, the level of exports from the Stavropol Territory during the period of 5 years increased in grain by $95 \%$, in meat-by 2.3 times, in milk-by $12.5 \%$, in vegetables-by 6.7 times, in fish-by 4, 5 times and decreased in fruit-by $56 \%$, and in eggs-by $23 \%$. The level of exports from Russia in general increased in grain by 2.5 times, in meat-by $14.3 \%$, in milk-by $5.3 \%$, in vegetables-by $5.8 \%$, and in eggs-by $42.9 \%$; although it decreased in potatos-by 2 times.

Comparison of import and export of products determines the vector of trade. Thus, Stavropol Territory market is export oriented in grain, meat and milk; Regional market is export oriented in grains and vegetables, whereas Russian market is export oriented in grains only.

Import depended industry is production of fruits and berries, since market availability factor is $>1$ at all assesed markets. At the same time, Territorial and Regional markets show higher degree of market availability in grain, meat, milk, eggs and fish; the national market availability is grains, milk, and eggs. Therefore the level of market concentration is reduced, and that leads to increased competition preasure from the foreign suppliers.

The red line for imports to become a threat is considered to be $10-35 \%$ on various commodities. Comparative characteristics of the import share in the sales volume of the Stavropol Territory, the North Caucasus region, and of the Russian Federation lead to the following conclusions: in the Stavropol Territory such situation is typical for fish-more than $70 \%$, fruits-more than $50 \%$, vegetables and meat-more than $20 \%$. In the North Caucasus Region these are fruit market-more than $80 \%$, meat market- more than $50 \%$, milk, vegetables and eggs-more than $20 \%$. In Russia the same is for fruit-more than $70 \%$, meat and milk-more than $20 \%$.

Analysis of the trends in food stock proves sufficient food security within all product groups and markets. However, the Regional market is experiencing decline in stocks for grain by $58 \%$, meat-by $3.2 \%$, eggs-by $13.3 \%$, National market shows decline in stocks for grains-by $36 \%$, and milk-by $3.1 \%$.

\subsection{The Study of Saturation Level of the Needs of the Population in Food}

The implemented assesment on market capacity must be supplemented with the study on how well the market meets the needs of the population in food, including availability of locally produced goods. This requires to consider the overall demand for agricultural produce as demand for food comodities. The study then shows a steady trend of growth in aggregated demand for agricultural products by 2.1 times against population growth in Stavropol Territory. In general, during the period of the assesment income generation with population increased by 1.7 times. Food expences increased by 1.9 times, and the share of food cash outflow within the overall consumers' disbursements increased. As a result, the ratio of household demand for agricultural products to the volume of agricultural production increased by 1.6 times.

To determine the market sufficiency level we used the scientific standards for consumption. Comparison of existing consumptions of basic food products in the Stavropol Territory, the North Caucasus Region and in the 
Russian Federation with the standard values, revealed that there is a persistent increase in the saturation level for regular nutritional needs.

Nutritional demands of the population in Stavropol Territory are met in grain products to more than $140 \%$, meat to $91.8 \%$, milk to $62.4 \%$, potatoes-to $122.4 \%$, vegetables-to $112.3 \%$, fruits-to $42.1 \%$, eggs-to $111.5 \%$, and fish-to $40 \%$. Nutritional demands of the population in North Caucasian Region are met in bread products to $122-127 \%$, meat-to $76,7-104,1 \%$, milk-to $71.8 \%$, potatoes-to $101-111,2 \%$, vegetables-to $111,5-127,7 \%$ fruit-to $56,8-83,2 \%$, eggs-to $82,7-116,2 \%$, fish-to $36,5-80 \%$. Nutritional demands of the population in Russia are met in bread products-by $119 \%$, meat-by $101.4 \%$, milk-by $75.5 \%$, potatoes-to $113.3 \%$, vegetables to- $83.8 \%$, fruits-to $63.2 \%$, eggs-to $106.2 \%$, and fish to $85.5 \%$. It is obvious that the market shows the evidence of products' substitutions, and it is proved by the ratio between the existent population incomes and the prevailing market prices for food (Anania \& Nisticò, 2014).

\subsection{Features of Supply and Demand for Agricultural Products}

It should be noted that pricing policy in agriculture has certain unique features related to this industry, which were developed amidst specific demands and supplies of agricultural products (Rakhmatuulin, 2006; Trukhachev, 2013). The demand is characterized by the following features:

- Demand for agricultural products, unlike most non-agricultural products has more clearly defined edges for saturation. It is closely linked with physiological limits of human consumption. This entails reduction of the share for food expenditures compared to total consumption expenditure in the environment of progressive development of society;

- Elasticity of demand reduces, as it is oriented to the income of the end users in the environment of mainstreaming of absolute population needs;

- Growth of demand is hindranced while the level of proposals accelerates.

Specialty features of agricultural offers are as follows:

- In contrast to the demand, agricultural offers have no clearly defined limits;

- In the environment of better developed social manpower and demand mainstreaming to the utter population requirements, the growth of the offer level in agriculture produce surpasses the level of demand;

- The offer of agricultural production depends on biological and climatic conditions;

- The industrious resources show immobility (land in agriculture is not actually a part of the inter-sectoral reallocation resources, inter-sectoral reallocation of other resources is difficult because of the presence of specific barriers to entry and exit in the industry) (Trukhachev, Kostyukova, Gromov, \& Gerasimov, 2014; Sobchenko, 2010).

Retail prices for selected food items structured to identify a specific part that raw materials (agricultural products) compile accounted for an average of 23 to $59 \%$.

Given the high import dependancy on a number of products there have been a comparison made to the prices of these imports and world prices. The data indicate a significant deviation of consumers' prices in the local market to those of the regional, national and the world markets. The world prices indexes are higher than Russian ones.

\subsection{The Results of the Ranking of Product Groups Agricultural Products}

The implemented study resulted in preparation of the market maps for Stavropol Territory that lay within the major agriculture product groups; the maps would allow to estimate the special aspects of the Territory agricultural market, identify factors influencing its development and detect the most favorable trends considering the market demands for the local produce.

Using the market maps the commodity groups are ranked by means of the selected indicators (Table 1), the analysis shows that within the contextual aggregated volume of the market the share of grain sales prevales whereas fish and fish products are the outsiders.

However, a combination of extra indicators made "Vegetables and table melons" a top priority group, overcoming "Grain", putting the groups "Meat", "Fruits and Berries", and "Fish and fish products" in third place, "Eggs and egg products "-in the fourth position "Milk and dairy products" is the fifth, with " Potatoes" concluding the rating group.

In order to make the final decision about the feasibility of a particular industry an analysis was made for strategic investment positions of agricultural commodity groups with the supplement of constructing an adapted BCG matrix (Figure 1). 
Table 1. Ranking of the agriculture comodity groups in Stavropol Territory using the system of the markket indicators

\begin{tabular}{|c|c|c|c|c|c|c|c|c|}
\hline & Grains & $\begin{array}{l}\text { Meat and } \\
\text { meat } \\
\text { produce }\end{array}$ & $\begin{array}{l}\text { Milk and } \\
\text { dairy } \\
\text { products }\end{array}$ & Potatoes & $\begin{array}{l}\text { Vegetables } \\
\text { and table } \\
\text { melons }\end{array}$ & $\begin{array}{l}\text { Fruit } \\
\text { and } \\
\text { berries }\end{array}$ & $\begin{array}{l}\text { Eggs and } \\
\text { egg } \\
\text { produce }\end{array}$ & $\begin{array}{l}\text { Fish and } \\
\text { seafood }\end{array}$ \\
\hline $\begin{array}{l}\text { Share in the total } \\
\text { volume of the } \\
\text { market capacity, } \%\end{array}$ & 42,2 & 3,9 & 12,5 & 9,1 & 10,2 & 3 & 18,6 & 0,5 \\
\hline Indicator Rank & 1 & 6 & 3 & 5 & 4 & 7 & 2 & 8 \\
\hline $\begin{array}{l}\text { Level of } \\
\text { self-reliance, } \%\end{array}$ & 366,0 & 106,8 & 107,1 & 72,3 & 73,9 & 48,2 & 95,4 & 26,4 \\
\hline Indicator Rank & 1 & 3 & 2 & 6 & 5 & 7 & 4 & 8 \\
\hline $\begin{array}{l}\text { Import } \\
\text { dependency, } \%\end{array}$ & 1,3 & 18,7 & 4,5 & 23,9 & 31,3 & 45,9 & 14,1 & 64,5 \\
\hline Indicator Rank & 8 & 5 & 7 & 4 & 3 & 2 & 6 & 1 \\
\hline $\begin{array}{l}\text { Import } \\
\text { consumption, } \%\end{array}$ & 6,9 & 28,3 & 5,2 & 29,1 & 37,4 & 53,9 & 15,7 & 76,2 \\
\hline Indicator Rank & 7 & 5 & 8 & 4 & 3 & 2 & 6 & 1 \\
\hline Export level,\% & 77,1 & 32,5 & 11,5 & 0,6 & 12,5 & 4,0 & 11,7 & 7,2 \\
\hline Indicator Rank & 1 & 2 & 5 & 8 & 3 & 7 & 4 & 6 \\
\hline $\begin{array}{l}\text { Agriculture } \\
\text { market availability } \\
\text { ratio }\end{array}$ & 0,8 & 0,6 & 0,2 & 0,4 & 0,7 & 1,2 & 0,3 & 0,8 \\
\hline Indicator Rank & 2 & 4 & 7 & 5 & 3 & 1 & 6 & 2 \\
\hline $\begin{array}{l}\text { Sales of imported } \\
\text { goods, } \%\end{array}$ & 1,7 & 28,3 & 5,2 & 28,9 & 36,9 & 53,9 & 15,7 & 75,6 \\
\hline Indicator Rank & 8 & 5 & 7 & 4 & 3 & 2 & 6 & 1 \\
\hline $\begin{array}{l}\text { Meeting, the } \\
\text { consumers' needs } \\
\text { level,\% }\end{array}$ & 143 & 84,9 & 60,7 & 118,6 & 100,8 & 39,1 & 106,9 & 36,8 \\
\hline Indicator Rank & 1 & 5 & 6 & 2 & 4 & 7 & 3 & 8 \\
\hline Ranks Total & 29 & 35 & 39 & 40 & 28 & 35 & 37 & 35 \\
\hline Group Ranking & 2 & 3 & 5 & 6 & 1 & 3 & 4 & 3 \\
\hline
\end{tabular}

Positions held by the particular businesses within the strategic trends defined by the BCG matrix recommend the selection of precise actions. The "Stars" must try to maintain or increase their share in the market. The "Cash Cows" need maintain or increase the proportion of business in the market. The "Dogs" should be satisfied with their status quo, otherwise reduce or eliminate this type of business.

The assessment results for strategic investment positions and market demand showed that the priority sub-sectors are: fruit growing, vegetable production both open air and greenhouse, poultry meat production, sheep and cattle growing.

The evaluation of already implemented investment projects encouraged rating of agricultural industries based on the socio-economic importance for the Stavropol Territory. Rating was based on the following indicators: the coefficient of the of investment projects' social importance; coefficient of the industries' investment activity; domestic net profit ratio of implemented investment projects; and payback period of the investment project.

Composed ratings allowed determine most feasible trends for investments into agriculture and industrial complex of the Stavropol Territory:

1) Agriculture processing capacities (construction of an oil extraction plants and feed mills), will contribute to complete process cycle (Sklyarova, Sklyarov, Gurnovich, Latysheva, Lapina, Kuleshova, Ostapenko, \& Voronin, 2013; Yarkova \& Svetlakov, 2013).

2) Poultry growing (turkeys).

3) Vegetables (greenhouses).

4) Logistics infrastructure (construction of vegetable and fruit storage capacities)

5) Vegetables (open air). 


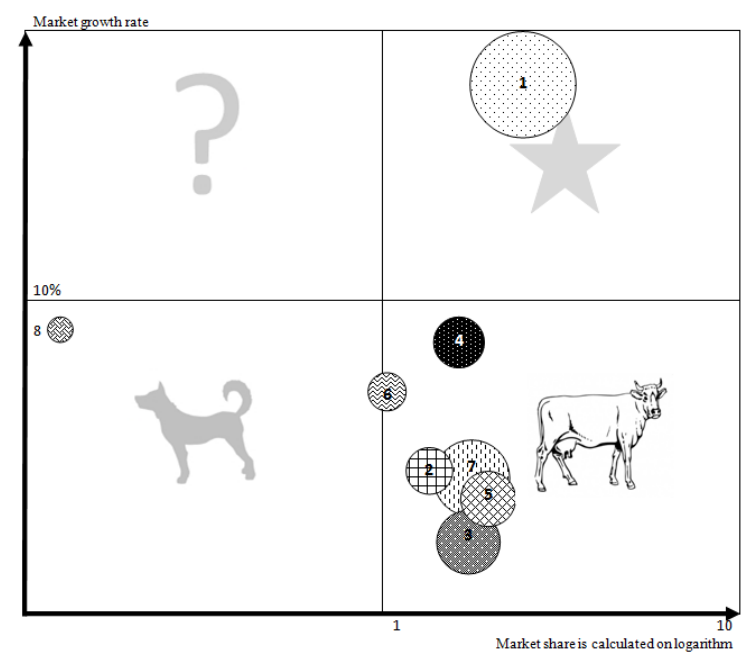

Figure 1. BCG matrix for strategic investment agricultural commodity groups in Stavropol Territory

Legend:
1. Grains
2. Meat and meat produce
3.Milk and dairy products
4. Potatoes
5. Vegetables and table melons
6. Fruits and berries

\section{Eggs and egg products 8 . Fish and seafood}

Table 2. Merged ranking of the agriculture industries in Stavropol Territory considering the level of their importance

\begin{tabular}{lllllll}
\hline $\begin{array}{l}\text { Types of } \\
\text { Produce }\end{array}$ & $\begin{array}{l}\text { Ranking the } \\
\text { produce } \\
\text { production and } \\
\text { resource } \\
\text { security }\end{array}$ & $\begin{array}{l}\text { Ranking the } \\
\text { produce } \\
\text { investment } \\
\text { attractiveness }\end{array}$ & $\begin{array}{l}\text { Ranking } \\
\text { Market } \\
\text { availability for } \\
\text { the produce }\end{array}$ & $\begin{array}{l}\text { Ranking } \\
\text { the } \\
\text { produce } \\
\text { social } \\
\text { value }\end{array}$ & $\begin{array}{l}\text { Merged } \\
\text { Ranking }\end{array}$ & Prioritizing \\
\hline $\begin{array}{l}\text { Vegetables } \\
\text { (greenhouses) }\end{array}$ & 4 & 3 & 1 & 5 & 13 & 2 \\
Fruit & 7 & 2 & 3 & 6 & 18 & 4 \\
Poultry Meat & 2 & 2 & 3 & 4 & 11 & 1 \\
Milk & 5 & 8 & 5 & 1 & 19 & 6 \\
Meat (beef) & 11 & 7 & 3 & 2 & 23 & 7 \\
Meat (lamb) & 7 & 7 & 3 & 7 & 24 & 8 \\
Sunflowers & 1 & 1 & 2 & 6 & 10 & 2 \\
Soy beans & 2 & 1 & 1 & 8 & 13 & 5 \\
$\begin{array}{l}\text { Vegetables } \\
\text { (open air) }\end{array}$ & 5 & 5 & & 3 & 14 & 3 \\
\hline
\end{tabular}

Overlapping the ratings in the frames of their production and resource security, investment attractiveness, market availability, and their social significance (based on the experts' evaluations) showed that the most promising sector in the Territory is poultry meat production (especially that of turkey) (Table 2).

\section{Conclusion}

This study allows to identify the most advantageous trends for developing agriculture sector in Stavropol Krai considering its supply security, production costs and market demands for the manufactured products. Priority industries include poultry meat production, vegetable growing, fruit growing.

Furthermore, based on the survey of the existing agriculture businesses in Stavropol Territory the following industries were defined as those that will serve diversification of the agribusiness and become an additional source of income for the population: floriculture, mushroom production, berries production (Sklyarova, Sklyarov, Gurnovich, Latysheva, Lapina, Kuleshova, Ostapenko, \& Voronin, 2013). 


\section{Acknowledgements}

This article was prepared under the State order, Contract \# 137/13 of 15.07.2013.

\section{References}

Anania, G., \& Nisticò, R. (2014). Price dispersion and seller heterogeneity in retail food markets. Food Policy, 44, 190-201. http://dx.doi.org/10.1016/j.foodpol.2013.12.004

Baquedano, F. G., \& Liefert, W. M. (2014). Market integration and price transmission in consumer markets of developing countries. Food Policy, 44, 103-114. http://dx.doi.org/10.1016/j.foodpol.2013.11.001

Evdokimova, L. P. (2009). Food security of the country and its evaluation. The rural economy. Abstract Journal, 1,8 .

Food security and agrarian problems of the Russian economy. (2011). The rural economy. Abstract Journal, 2, 269.

Garmann, S. (2014). Does globalization influence protectionism? Empirical evidence from agricultural support. Food Policy, 49(P1), 281-293. http://dx.doi.org/10.1016/j.foodpol.2014.09.004

Jones, K. E., \& Davidson, D. J. (2014). Adapting to food safety crises: Interpreting success and failure in the Canadian response to BSE. Food Policy, 49(P1), 250-258. http://dx.doi.org/10.1016/j.foodpol.2014.09.003

Rakhmatuulin, R. K. (2006). Common factors and specifics of market pricing for agricultural products. Candidate of Science in Economics: Theory of Economic (p. 195). Ufa.

Rudoi, E. V. (2011). Development of agriculture market in Siberia (theory, methodology, and practice) (p. 286). PHD in Economics. Economy and management (economics, organization and management of enterprises, industries and facilities. Agribusiness and agriculture). Novosibirsk.

Sklyarov, I. Y., \& Sklyarova, Y. M.. (2013). Development of Small Forms of Entrepreneurship and Agricultural Production in Russian Village. Middle-East Journal of Scientific Research, 17(4), 424-428.

Sklyarova, Y. M., Sklyarov, I. Y., Gurnovich, T. G., Latysheva, L. A., Lapina, E. N., Kuleshova, L. V., ..., Voronin, A. M. (2013). Food Market trends and development prospects for enterprises in Stavropol Territory in the WTO environment (p. 144). Monograph. Stavropol, Stavropol State Agricultural University, AGRUS.

Sklyarova, Y. M., Sklyarov, I. Y., Gurnovich, T. G., Latysheva, L. A., Lapina, E. N., Kuleshova, L. V., ..., Voronin, A. M. (2013). Integral assessment of the resource potentials of agribusinesses in Stavropol Territory (p. 136). Monograph. Stavropol, Stavropol State Agricultural University, AGRUS.

Sobchenko, N. V. (2010). Manufacture of milk products in the Stavropol Territory: Experiences and prospects. Regional Economics: Theory and Practice, 32(167), 63-67.

Syomin, A. N., \& Kibirov, A. Y. (2013). Basic directions and tools to increase investment attractiveness of the agricultural sector. Economy of Region, 3, 233-238. http://dx.doi.org/10.17059/2013-3-21

Tomilina, E. P., Glotova, I. I., \& Kuzmenko, I. P. (2013). Development of Integration Processes in the Traditional Sectors of Agriculture. Middle-East Journal of Scientific, 13, 178-182.

Trukhachev, V. I. (2013). Evaluation of socioecological and economic development of agricultural regions of Southern Russia. Business in law, 6, 291-295.

Trukhachev, V. I. (2013). Technique of socioecological and economic evaluation of sustainability of Southern Russia agricultural regions. Economy and Entrepreneurship, 12-13(41-43), 299-304.

Trukhachev, V. I., Kostyukova, E. I., Gromov, E. I., \& Gerasimov, A. N. (2014). Comprehensive socio-ecological and economic assessment of the status and development of Southern Russia agricultural regions. Life Science Journal, 11(5), 478-482.

Urban, G. (2010). Food security of the country. The rural economy. Abstract Journal, 2, 271.

Veeman, M., \& Veeman, T. (2004). Current issues in the economics of agriculture, food, and resources: Reshaping agriculture's contributions to society. Agricultural Economics, 31, 119-122. http://dx.doi.org/10. 1111/j.1574-0862.2004.tb00250.x

Yarkova, T. M., \& Svetlakov, A. G. (2013). The meaning of the state support development of the region's food reserves in the framework of the WTO. Economy of Region, 4, 157-167. http://dx.doi.org/10.17059/2013$4-16$

\section{Copyrights}

Copyright for this article is retained by the author(s), with first publication rights granted to the journal.

This is an open-access article distributed under the terms and conditions of the Creative Commons Attribution license (http://creativecommons.org/licenses/by/3.0/). 